\title{
MOLECULAR-GENETIC INVESTIGATIONS OF STURGEON (ACIPENSERIDAE). THEMATIC ENGLISH LANGUAGE BIBLIOGRAPHY
}

\author{
M. Simon, seemann.sm@gmail.com, Institute of Fisheries NAAS, Kyiv
}

Purpose. Forming a thematic bibliographic list of English-language publications on certain issues of molecular genetic and cytogenetic studies of sturgeon (Acipenseridae).

Methods. The complete and selective methods were applied in the process of the systematic search. The bibliographic core was made up of literary sources from electronic archives of worldrenowned specialized scientific journals. In particular: Journal of Applied Ichthyology, Conservation Genetics, Fish Physiology and Biochemistry, Canadian Journal of Fisheries and Aquatic Sciences, Transactions of the American Fisheries Society, Chinese Journal of Oceanology and Limnology etc.

Results. A thematic list of the main publications was composed: thematic scientific collections, materials of international scientific and practical conferences, scientific articles and abstracts of dissertations. It consists of 156 English-language papers. Presented publications cover the time interval for the last thirty years. The literary sources are arranged in alphabetical order by author or title, and described according to DSTU 8302:2015 "Information and documentation. Bibliographic reference. General principles and rules of composition", with the amendments (code UKND 01.140.40), as well as in accordance with the requirements of APA style - international standard of references.

Practical value. The prepared list may be useful for scientists, practitioners, students, whose sphere of interests is related to issues of molecular genetic and cytogenetic research, as well as biotechnology.

Key words: sturgeon (Acipenseridae), aquaculture, molecular genetic studies, sturgeon viruses, polyploidy, phylogenetic analysis, RAPD markers, mitochondrial DNA, cytogenetic studies, hybridization.

\section{МОЛЕКУЛЯРНО-ГЕНЕТИЧНІ ДОСЛІДЖЕННЯ РИБ РОДИНИ ОСЕТРОВИХ (ACIPENSERIDAE). ТЕМАТИЧНА АНГЛОМОВНА БІБЛІОГРАФІЯ}

М. Ю. Симон, seemann.sm@gmail.com, Інститут рибного господарства НАAН України, м. Київ

Мета. Формування довідкового бібліографічного переліку англомовних публікацій з питань молекулярно-генетичних та цитогенетичних досліджень риб з родини осетрових (Acipenseridae).

Методика. У процесі підготовки тематичного списку, в ході системного пошуку було застосовано чілісний та вибірковий методи. Бібліографічне ядро складали літературні джерела з електронних архівів всесвітньовідомих спеціалізованих наукових журналів, зокрема: Journal of Applied Ichthyology, Conservation Genetics, Fish Physiology and Biochemistry, Canadian Journal of Fisheries and Aquatic Sciences, Transactions of the American Fisheries Society, Chinese Journal of Oceanology and Limnology ma iH.

Результати. Сформовано тематичний бібліографічний перелік основних робіт: тематичних наукових збірників, матеріалів міжнародних науково-практичних конференцій,

(C) M. Simon, 2018

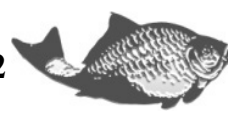


наукових статей і авторефрератів дисертацій. Він налічує 156 англомовних джерел. Представлені публікації охоплюють часовий інтервал за останні тридиять років. Літературні джерела розміщені у алфавітному порядку за автором чи назвою, описані згідно з ДСТУ 8302:2015 «Інформачія та документація. Бібліографічне посилання. Загальні положення та правила складання», із урахуванням поправок (код УКНД 01.140.40), а також відповідно до вимог оформлення списку літератури за міжнародним стандартом APA style.

Практична значимість. Підготовлений перелік може бути корисним для науковців, практиків, студентів, срера інтересів яких стосується питань молекулярно-генетичних та цитогенетичних досліджень, а також біотехнологій.

Ключові слова: осетрові (Acipenseridae), аквакультура, молекулярно-генетичні дослідження, віруси у осетрових, філогенетичний аналіз, RAPD-маркери, мітохондріальна ДнК, читогенетичні дослідження, гібридизація.

\section{МОЛЕКУЛЯРНО-ГЕНЕТИЧЕСКИЕ ИССЛЕДОВАНИЯ РЫБ CEMЕЙСТВА ОСЕТРОВЫХ (ACIPENSERIDAE). ТЕМАТИЧЕСКАЯ АНГЛОЯЗЫЧНАЯ БИБЛИОГРАФИЯ}

\section{М. Ю. Симон, seemann.sm@gmail.com, Институт рыбного хозяйства НАAН} Украины, г. Киев

Цель. Формирование справочного библиографического перечня англоязычных публикаций по вопросам молекулярно-генетических и цитогенетических исследований рыб семейства осетровых (Acipenseridae).

Методика. В процессе подготовки тематического списка, в ходе системного поиска были применены целостный и выборочный методы. Библиографическое ядро составляли литературные источники из электронных архивов всемирно известных специализированных научных журналов, в частности: Journal of Applied Ichthyology, Conservation Genetics, Fish Physiology and Biochemistry, Canadian Journal of Fisheries and Aquatic Sciences, Transactions of the American Fisheries Society, Chinese Journal of Oceanology and Limnology u $\partial p$.

Результаты. Сфрормирован тематический библиографический перечень основных работ: тематических научных сборников, материалов международных научнопрактических конференций, научных статей и авторефератов диссертаций. Он насчитывает 156 англоязычных источников. Представленные публикации охватывают временной интервал за последние тридиать лет. Литературные источники размещены в алфавитном порядке по автору или названию, описаны по ГОСТ 8302: 2015 «Информация и документация. Библиографические ссылки. Общие положения и правила составления», с учетом поправок (код УКНД 01.140.40), а также в соответствии с требованиями к оформлению списка литературы по международному стандарту APA style.

Практическая значимость. Подготовленный перечень может быть полезным для ученых, практиков, студентов, сфера интересов которых касается вопросов молекулярногенетических и цитогенетических исследований, а также биотехнологий.

Ключевые слова: осетровые (Acipenseridae), аквакультура, молекулярно-генетические исследования, вирусы у осетровых, полиплоидия, филогенетический анализ, RAPD-маркеры, митохондриальная ДНК, цитогенетические исследования, гибридизация.

1. A fixed allele at microsatellite LS-39 is characteristic for the black caviar producer Acipenser stellatus // Jenneckens I. et al. // Journal of Applied Ichthyology. 2001. 17. P. 39-42.

2. Adeno-like virus associate with a disease of cultured white sturgeon (Acipenser transmontanus) / Hedrick R. P. et al. // Canadian Journal of Fisheries and Aquatic 
Sciences. 1985. Vol. 42. P. 1321-1325.

3. Adkison M. A., Cambre M., Hedrick R. P. Identification of an iridovirus in Russian sturgeon (Acipenser gueldenstaedti) from northern Europe // Bull. Eur. Assoc. Fish Pathol. 1998. Vol. 18. P. 29-32.

4. Alavi S. M. H. Sperm motility analysis for sturgeons // Cryopreservation of sturgeon sperm, 28 October 2009 : International Workshop : proceed. Wuhan, China, 2009. P. 12-20.

5. Analysis of mitochondrial and nuclear DNA markers in old museum sturgeons yield insights about the species existing in Western Europe: A. sturio, A. naccarii and A. oxyrinchus. / Garrido-Ramos M. A. et al. // Springer Science \& Business Media. 2009. P. 25-49.

6. An iridovirus infection of the integument of the white sturgeon (Acipenser transmontanus) / Hedrick R. P. et al. // Diseases of Aquatic Organisms. 1990. Vol. 6. P. 39-40.

7. Arefjev V. A. Cytogenetic aspects of differences in the quality of spawners of reciprocal hybrids between "bester" and beluga sturgeon // Biol. Principles of commercial culture of sturgeons : collected papers. Moscow : VNIRO, 1991. P. $134-150$.

8. Arefjev V. A. Kariotype variability in successive generations after hybridization between the great sturgeon, Huso huso (L.), and the sterlet, Acipenser ruthenus (L.) // Journal of Fish Biology. 1989. Vol. 35. P. 819-828.

9. Arefjev V. A., Nikolaev A. I. Induced polyploidy in sturgeons: back to the problem in Russia // 2nd Int. Simp. on Sturgeons : abst. bull. Moscow : VNIRO, 1993. P. $31-32$.

10. Artyukhin E. N. Morphological phylogeny of the Order Acipenseriformes // The Sturgeon Quarterly. 1995. Vol. 3. P. 6-8.

11. Barmintsev V. A., Chudinov O. S., Abramova A. B. Molecular and biological methods of identification and certification of sturgeons and their products // Fisheries and Aquaculture Journal. 2001. Vol. 1. P. 70-71.

12. Bemis W. E., Findeis E. K. The sturgeons' plight // Nature. 1994. Vol. 370. P. 602.

13. Beyea M. M., Benfey T. J., Kieffer J. D. Hematology and stress physiology of juvenile diploid and triploid shortnose sturgeon (Acipenser brevirostrum) // Fish Physiology and Biochemistry. 2005. Vol. 31. P. 303-313.

14. Billard R., Lecointre G. Biology and conservation of sturgeon and paddlefish // Reviews in Fish Biology and Fisheries. 2000. Vol. 10. P. 355-392.

15. Biochemical analysis of decrease in phenotypic diversity in the Volgo-Caspian Russian sturgeon population / Vasil'ev A. S. et al. // Journal of Applied Ichthyology. 1999. Vol. 15. P. 284-285.

16. Birstein V. J. Stugeon species and hybrids: can hybrids produce caviar? // Environmental policy and law. 2000. Vol. 32. P. 210-214.

17. Birstein V. J., Hanner R., DeSalle R. Phylogeny of the Acipenseriformes: cytogenetic and molecular approaches. // Environmental Biology of Fishes. 1997. Vol. 48. P. 127-155.

18. Birstein V. J., Betts J., De Salle R. Molecular identification of Acipenser sturio specimens: A warning note for recovery plans // Journal of Biological Conservation. 1998. Vol. 84. P. 97-101.

19. Birstein V. J., De Salle R. Molecular phylogeny of Acipenserinae // Molecular phylogenetics and evolution. 1998. Vol. 9. P. 141-155. 
20. Birstein V. J., Doukakis P., De Salle R. Molecular phylogeny of Acipenserinae and black caviar species identification // Journal of Applied Ichthyology. 1999. Vol. 15. P. $12-16$.

21. Birstein V. J., Doukakis P., De Salle R. Polyphyletic genetic structure of the Russian sturgeon and caviar species identification // Journal of Conservation genetics. 2000. Vol. 1. P. 81-88.

22. Birstein V. J., Doukakis P., DeSalle R. Polyphyly of mtDNA lineages in the Russian sturgeon, Acipenser gueldenstaedtii: forensic and evolutionary implications // Journal of Conservation Genetics. 2000. Vol. 1. P. 81-88.

23. Birstein V. J., Poletaev A. I., Goncharov B. F. The DNA content in Eurasian sturgeon species determined by flow cytometry // Journal of Cytometry. 1993. Vol. 14. P. 337-383.

24. Birstein V. J., Vasil'ev V. P. Tetraploid-octoploid relationships and karyological evolution in the order Acipenseriformes (Pisces): karyotypes, nucleoli, and nucleolus-organizer regions in four acipenserid species // Journal of Conservation Genetics. 1987. Vol. 73. P. 3-12.

25. Bischof R., Szalanski A. L. Mitochondrial-DNA variation in pallid and shovelnose sturgeons, Scaphirhynchus (Pisces: Acipenseridae). // Trans. Nebr. Acad. Sci. 2000. Vol. 26. P. 19-21.

26. Blacklidge K. H., Bidwell C. A. Three ploidy levels indicated by genome quantification in Acipenseriformes of North America // Journal of Heredity. 1993. Vol. 84. P. 427-430.

27. Bowen B. W., Avise J. C. Genetic structure of Atlantic and Gulf of Mexico populations of sea bass, menhaden, and sturgeon: influence of zoogeographic factors and life-history patterns. // Marine Biology. 1990. Vol. 107. P. 371-381.

28. Brown J. R., Beckenbach A. T., Smith M. J. Intraspecific DNA sequence variation of the mitochondrial control region of white sturgeon (Acipenser transmontanus). // Molecular Biology Evol. 1993. Vol. 10. P. 326-341.

29. Brown J. R., Beckenbach A. T., Smith M. J. Mitochondrial DNA length variation and heteroplasmy in populations of white sturgeon (Acipenser transmontanus) // Journal of Conservation Genetics. 1992. Vol. 132. P. 221-228.

30. Brown J. R., Beckenback A. T., Smith M. J. Influence of Pleistocene glaciations and human intervention upon mitochondrial DNA diversity in white sturgeon (Acipenser transmontanus) populations // Canadian Journal of Fisheries and Aquatic Sciences. 1992. Vol. 49. P. 358-367.

31. Characteristics and pathogenicity of a novel herpesvirus isolated from adult and sub adult white sturgeon (Acipenser transmontanus) / Watson L. R. et al. // Diseases of Aquatic Organisms. 1995. Vol. 22. P. 199-210.

32. Characteristics of two viruses isolated from white sturgeon, Acipenser transmontanus / Hedrick R. P. et al. // Second Intern. Symp. Virus. Lower Verteb. : proceed. / ed. Fryer-Corvallis J. L. OR : Oregon State Univer. Press, 1991. P. 165174.

33. Characterization of the Sox9 gene in European Atlantic sturgeon (Acipenser sturio) / Hett A. K. et al. // Journal of Heredity. 2005. Vol. 96. P. 150-154.

34. Choudhury A., Dick T. A. The historical biogeography of sturgeons (Osteichthyes: Acipenseridae): a synthesis of phylogenetics, palaeontology and palaeogeography // Journal of Biogeography. 1998. Vol. 25. P. 623-640. 
35. Complete mitochondrial DNA sequence analysis of Ponto-Caspian sturgeon species / Rastorguev S. et al. // Journal of Applied Ichthyology. 2008. Vol. 24. P. 46- 49.

36. Cryopreservation and short-term storage of sturgeon sperm / Billard R. et al. // Aquaculture. 2004. Vol. 236. P. 1-9.

37. Cryopreservation of Chinese sturgeon (Acipenser sinensis) sperm / Liu L. et al. // Journal of Applied Ichthyology. 2006. Vol. 22. P. 384-388.

38. Cytogenetic characterization of cell lines from six sturgeon species / Lanfredi M. et al. // Journal of Applied Ichthyology. 1999. P. 282-283.

39. Cytogenetic characterization of cell lines from three sturgeon species / Fontana F. et al. // Journal of Caryologia. 1997. Vol. 50. P. 91-95.

40. DeSalle R., Birstein V. J. PCR identification of black caviar // Nature. 1996. Vol. 381. P. 197-198.

41. DeWoody J. A., Avise J. C. Microsatellite variation in marine, freshwater and anadromous fishes compared with other animals // Journal of Fish Biology. 2000. Vol. 56. P. 461- 473.

42. Degani G. Availability of protein and energy from throat protein sources in hybrid sturgeon Acipenser guldenstadti $\times$ A. bester // Aquaculture Research. 2002. Vol. 33. P. 725-727.

43. Di Lauro M. N., Kaboord W. S., Walsh R. A. Sperm-cell ultrastructure of North American sturgeons. IV. The lake sturgeon (Acipenser fulvescens Rafinisque, 1817) // Canadian Journal of Zoology. 2000. Vol. 78. P. 438 - 447.

44. Distribution of mitochondrial DNA variation in lake sturgeon (Acipenser fulvescens) from the Moose River basin, Ontario, Canada / Ferguson M. M. et al. // Journal of Fish Biology. 1993. Vol. 43. P. 91-101.

45. Distribution, biology and hybridization of Scaphirhynchus albus and $S$. platorynchus in the Missouri and Mississippi rivers. / Carlson D. M. et al. // Environmental Biology of Fish. 1985. Vol. 14. P. 51-59.

46. Dingerkus G., Howell W. M. Karyotypic analysis and evidence of tetraploidy in the North American paddlefish (Polyodon spathula) // Science. 1976. Vol. 194. P. $842-843$.

47. Differentiation of pallid sturgeon and shovelnose sturgeon using an index based on meristics and morphometrics / Wills P. S. et al. // American Fisheries Society Symp. 2002. Vol. 28. P. 249-2258.

48. Doszpoly A., Shchelkunov I. S. Partial genome analysis of Siberian sturgeon alloherpesvirus suggests its close relation to AciHV-2 // Acta Veterinaria Hungarica. 2010. Vol. 58. P. 269-274.

49. Doukakis P., Birstein V. J., De Salle R. Intraspecific structure within three caviarproducing sturgeons (Acipenser gueldenstaedtii, A. stellatus and Huso huso) based on mitochondrial DNA analysis // Journal of Applied Ichthyology. 2005. Vol. 21. P. $457-460$.

50. Conservation and management implications of finescale genetic structure of Gulf Sturgeon in the Pascagoula River, Mississippi / Dugo M. A. et al. // Journal of Applyed Ichtyology. 2004. Vol. 20, P. 243-251.

51. Established cell lines from three sturgeon species / Foster O. et al. // The Sturgeon Quarterly 1995. Vol. 3. P. 6-7.

52. Evidence of mitochondrial DNA clones of Siberian sturgeon, Acipenser baerii, within Russian sturgeon, Acipenser gueldenstaedtii, caught in the River Volga / 
Jenneckens I. et al. // Ecol. Lett. 2000. Vol. 3. P. 503-508.

53. Evolution of ancient satellite DNAs in sturgeon genomes. / Robles, F. et al. // Gene. 2004. Vol. 338. 133-142.

54. Findeis E. K. Osteology and phylogenetic interrelationships of sturgeons (Acipenseridae) // Environmental Biology of Fishes. 1997. Vol. 48. P. 73-126.

55. First detection and identification of koi herpesvirus (KHV) in Russian sturgeon (Acipenser gueldenstaedtii) and Atlantic sturgeon (Acipenser oxyrinchus) til genetic relationships among herpes-like viruses isolated from sturgeon / Kelly G. O. et al. // Journal of Aquatic Animal Health. 2005. Vol. 17. P. 297-303.

56. Fish cell culture: two newly developed cell lines from atlantic sturgeon (Acipenser oxyrhynchus) and guppy (Poecilia reticulata) / Li M. F. et al. // Canadian Journal of Zoology. 1985. Vol. 63. P. 2867-2874.

57. Flajshans M., Vajcova V. Odd ploidy levels in sturgeon suggest a backcross of interspecific hexaploid sturgeon hybrids to evolutionary tetraploid and octaploid parental species // Folia Zoologica. 2000. Vol. 49. P. 133-138.

58. Fontana F. Chromosomal nucleolar organizer regions in four sturgeon species as markers of karyotype evolution in Acipenseriformes (Pisces) // Genome. 1994. Vol. 37. P. $888-892$.

59. Fontana F., Jankovic D., Zivkovic S. Somatic hromosomes of Acipenser ruthenus L. // Archives of biological sciences. 1975. Vol. 21. P. 1-2.

60. Fontana F., Tagliavini J., Congiu L. Sturgeon genetics and cytogenetics: recent advancements and perspectives // Journal of Conservation Genetics. 2001. Vol. 111. P. 359-373.

61. Forlani A., Fontana F., Congiu L. Isolation of microsatellite loci from the endemic and endangered Adriatic Sturgeon (Acipenser naccarii) // Journal of Conservation Genetics. 2008. Vol. 9. P. 461-463.

62. Gardiner B. G. Sturgeons as living fossils: circumscription, phylogeny, polyploidy, and possible hybrid speciation // American Journal of Botany. 2004. Vol. 91. P. 707-723.

63. Genetic issues in aquatic species management: the shortnose sturgeon (Acipenser brevirostrum) in the south-eastern United States / Quattro J. M. et al. // Journal of Conservation Genetic. 2002. Vol. 3. 155-166.

64. Genetic comparison of lake sturgeon populations: differentiation based on allelic frequencies at seven microsatellite loci / Mc Quown E. C. et al. // Journal Great Lakes Res. 2003. Vol. 29. P. 3-13.

65. Genetic differences and resemblance between Acipenser persicus and Acipenser gueldenstaedtii by means of RAPD technique / Gharaei A. et al. // Iranian Journal of Fisheries Sciences. 2005. Vol. 14. P. 91-102.

66. Genetic differentiation of three key anadromous fish populations of the Hudson River / Waldman J. R. et. al. // Estuaries. 1996. Vol. 19. P. 759-768.

67. Genetic discrimination of middle Mississippi River Scaphirhynchus sturgeon into pallid, shovelnose, and putative hybrids with multiple microsatellite loci / Schrey A. W. et al. // Journal of Conservation Genetics. 2007. Vol. 8. P. 683-693.

68. Genetic distinction of pallid, shovelnose, and alabama sturgeon: emerging species and the US endangered species act / Campton D. E. et al. // Journal of Conservation Genetics. 2000. Vol. 1. P. 17-32.

69. Genetic divergence between Acipenser oxyrinchus oxyrinchus and Acipenser oxyrinchus desotoi as assessed by mitochondrial DNA sequencing analysis / Ong 
T.-L. et al. // Copeia. 1996. Vol. 2. P. 464-469.

70. Genetic identification of western Mediterranean sturgeons and its implication for conservation / de la Herran R. et al. // Journal of Conservation Genetics. 2004. Vol. 5. P. 545-551.

71. Genetic structure of Atlantic sturgeon populations based on mitochondrial DNA control region sequenses / Wirgin I. et al. // Transactions of the American Fisheries Society. 2000. Vol. 129. P. 476-486.

72. Genome duplication events and functional reduction of ploidy levels in sturgeon (Acipenser, Huso and Scaphirhynchus) / Ludwig A. et al. // Journal of Conservation Genetics. 2001. Vol. 158. P. 1203-1215.

73. Genomic organization and evolution of the $5 \mathrm{~S}$ ribosomal DNA in the ancient fish sturgeon / Robles F. et al. // Genome. 2005. Vol. 48. P. 18-28.

74. Gisbert E., Doroshov S. Allometric growth in green sturgeon larvae // Journal of Applied Ichthyology. 2006. Vol. 22. P. 202-207.

75. Grande L., Bemis W. E. Osteology and phylogenetic relationships of fossil and recent paddlefishes (Polyodontidae) with comments on the interrelationships of Acipenseriformes // Journal of Vertebrate Paleontology. 1991. Vol. 11. P. 1-121.

76. Guenette S., Fortin R., Rassart E. Mitochondrial DNA variation in lake sturgeon (Acipenser fulvescens) from the St. Laurence River and James Bay Drainage Basins in Quebec, Canada // Canadian Journal of Fisheries and Aquatic Sciences. 1993. Vol. 50. P. 659-664.

77. Hatchery manual for white sturgeon, Acipenser transmontanus R., with application to other North American Acipenseridae / Conte F. S. et al. Oakland: Div. Agric. Mat. Res., University of California, 1988. P. 88.

78. Henderson-Arzapalo A., King T. L. Novel microsatellite markers for Atlantic sturgeon (Acipenser oxyrinchus) population delineation and broodstock management // Molecular ecology Resources. 2002. Vol. 2. P. 437-439.

79. Heteroplasmy in the mtDNA control region of sturgeon (Acipenser, Huso and Scaphirhynchus) / Ludwig A. et al. // Journal of Conservation Genetics. 2000. Vol. 156. P. 1933-1947.

80. Hett A. K., Ludwig A. SRY-related (Sox) genes in the genome of European Atlantic sturgeon (Acipenser sturio) // Genome. 2005. Vol. 48. P. 181-186.

81. Hine P. M., Wain J. M. Ultrastructural and citochemical observations on the granulocytes of the sturgeons, Asipenser brevirostrum (Chondrostei) / Journal of Fish Biology. 1988. Vol. 33. P. 235-245.

82. Hybridization of Acipenseridae and its practical significance / Barannikova I. A. et al. // Rep. FAO/UNDP (TA). Rome, 1971. P. 328-334.

83. Identification of interspecific hybrids by amplified fragment length polymorphism: the case of sturgeon / Congiu L. et al. // Molecular ecology Resources. 2001. Vol. 10. P. 2355-2359.

84. Inheritance of microsatellite loci in the polyploid lake sturgeon (Acipenser fulvescens) / Pyatskowit J. D. et al. // Genome. 2001. Vol. 44. P. 185-191.

85. Isolation and characterization of microsatellites in the Adriatic sturgeon (Acipenser naccarii) / Zane L. et al. // Molecular Ecology Notes. 2002. Vol. 2. P. 586-588.

86. Isolation of an epitheliotropic herpesvirus from white sturgeon (Acipenser transmontanus) / Hedrick R. P. et al. // Diseases of Aquatic Organisms. 1991. Vol. 11. P. 49-56. 
87. Jahnichen H., Kohlmann R., Rennert B. Juvenile growth of A. ruthenus and 4 different sturgeon hybrids : 3 International symposium on sturgeon, July 811.1997 : abstracts. Piacenza, Italy. P. 71-72.

88. Kempter J. First detection and identification of koi herpesvirus (KHV) in Russian sturgeon (Acipenser gueldenstaedtii) and Atlantic sturgeon (Acipenser oxyrinchus) // 7 International Symposium on Viruses of Lower Vertebrates : proceed. Oslo, Norway, 2007. P. 15.

89. Keyvanshokooh S., Pourkazemi M., Katbassi M. R. The RAPD technique failed to identify sex-specific sequences in beluga (Huso huso) // Journal of Applied Ichthyology. 2007. Vol. 23. P. 1-2.

90. King T. L., Lubinski B. A., Spidle A. P. Microsatellite DNA variation in Atlantic sturgeon (Acipenser oxyrinchus oxyrinchus) and cross-species amplification in Acipenseridae // Journal of Conservation Genetics. 2001. Vol. 2. P. 103-119.

91. Krieger J. Molecular phylogenetics and evolution of the North American sturgeon and paddlefish (Order Acipenseriformes) : diss. thesis ... PhD. Columbus, Ohio, USA : Ohio State Univ., 2000. 248 p.

92. Krieger J., Fuerst P. A. Characterization of nuclear 18S rRNA gene sequence diversity and expression in an individual lake sturgeon (Acipenser fulvescens) // Journal of Applied Ichthyology. 2004. Vol. 20. P. 433- 439.

93. Krieger J., Fuerst P. A. Evidence of multiple alleles of the nuclear $18 \mathrm{~S}$ ribosomal RNA gene in sturgeon // Journal of Applied Ichthyology. 2002. Vol. 18. P. 290297.

94. Krieger J., Fuerst P. A. Evidence for a slowed rate of molecular evolution in the order Acipenseriformes // Molecular Biology Evolution. 2002. Vol. 19. P. 891897.

95. Krieger J., Fuerst P. A., Cavender T. M. Phylogenetic relationships of the North American sturgeons (Order Acipenseriformes) based on mitochondrial DNA sequences // Molecular Phylogenetics and Evolution. 2000. Vol. 16. P. 64-72.

96. Kuhajda B. R., Mayden R. L. Morphological comparisons of hatchery-reared specimens of Scaphirhynchus albus, S. platorhynchus, and $S$. albus, $S$. platorhynchus hybrids : Final Report US Fish and Wildlife Service Bismarck. North Dakota, 2001. 119 p.

97. Kurobe T., Kelly G. O., Waltzek T. B. Revised phylogenetic relationships among herpesviruses isolated from sturgeons // Journal of Aquatic Animal Health. 2008. Vol. 20. P. 96-102.

98. Length variation, heteroplasmy and sequence divergence in the mitochondrial DNA of four species of sturgeon (Acipenser) / Brown J. R. et al. // Journal of Conservation Genetics. 1996. Vol. 142. P. 525-535.

99. Length heteroplasmy of sturgeon mitochondrial DNA: an illegitimate elongation model / Buroker N. E. et al. // Genetics. 1990. Vol. 124. P. 157-163.

100. Low genetic variability in paddlefish populations / Carlson D. M. et al. // Copeia. 1982. Vol. 3. P. 721-723.

101. Ludwig A. A sturgeon view on conservation genetics // European Journal of Wild Research. 2006. Vol. 52. P. 3-8.

102. Ludwig A., Kirschbaum F. Comparison of mitochondrial DNA sequences between the European and the Adriatic sturgeon // Journal of Fisheries Biology. 1998. Vol. 52. P. $1289-1291$.

103. Ludwig A., Debus L., Jenneckens I. A molecular approach for trading control of black caviar // International Review of Hydrobiology. 2002. Vol. 87. P. 661-674. 
104. May B., Krueger C. C., Kincaid H. L. Genetic variation at microsatellite loci in sturgeon: primer sequence homology in Acipenser and Scaphirhynchus // Canadian Journal of Fisheries and Aquatic Sciences. 1997. Vol. 54. P. 1542-1547.

105. May B., Kuhajda B. R. Systematics, taxonomy, and conservation status of the endangered Alabama sturgeon Scaphirhynchus suttkusi William and Clemmer (Actinopteiygii, Acipenseridae) // Copeia. 1996. Vol. 2. P. 241-275.

106. McQuown E. C., Gall G. A. E., May B. Characterization and inheritance of six microsatellite loci in lake sturgeon // Transactions of the American Fisheries Society. 2002. Vol. 131. P. 299-307.

107. Microsatellite analysis of genetic variation in sturgeon: new primer sequences for Scaphirhynchus and Acipenser. / McQuown E. C. et al. // Transactions of the American Fisheries Society. Vol. 129. P. 1380-1388.

108. Mitochondrial DNA length variation and heteroplasmy in the Chinese sturgeon (Acipenser sinensis) / Zhang S.-M. et al. // Acta Genetica Sinica 1999. Vol. 26. P. $18-25$.

109. Mitochondrial DNA sequences of six sturgeon species and phylogenetic relationships within Acipenseridae / Tagliavini J. et al. // Journal of Applied Ichthyology. 1999. Vol. 15. P. 17-22.

110. Miracle A. L., Campton D. E. Tandem repeat sequence variation and length heteroplasmy in the mitochondrial DNA D-loop of the threatened Gulf of Mexico sturgeon A. oxyrichus desotoi // Journal of Heredity. 1995. Vol. 86. P. 22-21.

111. Molecular genetic analysis among subspecies of two Eurasian sturgeon species, Acipenser baerii and A. stellatus / Doukakis P. et al. // Molecular ecology Resources. 1999. Vol. 12. P. 117-127.

112. Morphological and genetic variation among Shortnose Sturgeon (Acipenser brevirostrum) from Adjacent and Distant Rivers / Walsh M. G. et al. // Estuaries. 2001. Vol. 24. P. 41- 48.

113. Motility analysis and energetics of the Siberian sturgeon Asipenser baeri spermatozoa / Billard R. et al. // Journal of Applied Ichthyology. 1999. Vol. 15. P. 199-203.

114. Motility and fertilizing capability of cryopreserved Acipenser ruthenus L. sperm / Jahnichen M. et al. // Journal of Applied Ichthyology. 1999. Vol. 15. P. 204-206.

115. Nonconcordant evolutionary history of maternal and paternal lineages in Adriatic sturgeon / Ludwig A. et al. // Molecular Ecology. 2003. Vol. 12. P. 3253-3264.

116. Objective analysis of sperm motility in the lake sturgeon (A. fulvescens): activation and inhibition conditions / Toth G. P. et al. // Aquaculture. 1994. Vol. 154. P. 337-348.

117. Occurrence of white sturgeon iridovirus infections among cultured white sturgeon in the Pacific Northwest / La Patra S. E. et al. // Aquaculture. 1994. Vol. 126. P. 201-210.

118. Ovarian development and serum sex steroid and vitellogenin profiles in the female cultured sturgeon hybrid, the bester / Mojazi Amiri B. et al. // Journal of Fish Biology. 1996. Vol. 47. P. 1164-1178.

119. Ontogenetic behavior and migration of Volga river Russian Sturgeon, Acipenser gueldenstaedtli, with a note on adaptive significance of body color / Kynard B. et al. // Environmental Biology of Fish. 2002. Vol. 65. P. 411- 421.

120. Phelps S. R., Allendorf F. W. Genetic identity of pallid and shovelnose sturgeon (Scaphirhynchns albus and S. platorynchus) // Copeia. 1983. Vol. 3. P. 696-700. 
121. Population aggregation analysis of three caviar-producing species of sturgeons and implications for the species identification of black caviar / Birstein V. J. et al. // Journal of Conservation Biology. 1998. Vol. 12. P. 766-775.

122. Population genetic analysis of white sturgeon (Acipenser fulvescens) in the Fraser River / Smith C. T. et al. // Journal of Applied Ichthyology. 2002. Vol. 18. P. 307-312.

123. Population genetic structure and genetic diversity of the Chinese sturgeon (Acipenser sinensis) based on random amplified polymorphic DNA analysis / Zhang S.-M. et al. // Chinese Journal of Oceanology and Limnology. 2000. Vol. 31. P. 1-7.

124. Population genetics of shortnose sturgeon Acipenser brevirostrum based on mitochondrial DNA control region sequences / Grunwald G. et al. // Molecular ecology Resources. 2002. Vol. 11. P. 1885-1898.

125. Pourkazemi M., Skibinski D. O. F., Beardmore J. A. Application of mtDNA dloop region for the study of Russian sturgeon population structure from Iranian coastline of the Caspian Sea // Journal of Applied Ichthyology. 1999. Vol. 15. P. $23-28$.

126. Reproductive isolation in sympatric populations of pallid and shovelnose sturgeon / Tranah G. J. et al. // North American Journal of Fisheries Management. 2001. Vol. 21. P. 367-373.

127. Richmond A. M., Kynard B. Ontogenic Behaviour of Shortnose Sturgeon, Acipenser brevirostrum // Copeia. 1995. Vol. 1. P. 172-182.

128. Robinson M. R., Ferguson M. M. Genetics of North American Acipenseriformes // Sturgeons and Paddlefishes of North America / LeBreton G. T. O. et al. Netherlands : Springer, 2004. P. 217-230.

129. Rodzen J. A., Famula T. R., May B. Estimation of parentage and relatedness in the polyploid white sturgeon (Acipenser transmontanus) using a dominant marker approach for duplicated microsatellite loci // Aquaculture. 2004. Vol. 232. P. $165-182$.

130. Rodzen J. A., May B. Inheritance of microsatellite loci in the white sturgeon (Acipenser transmontanus) // Genome. 2002. Vol. 45. P. 1064-1076.

131. Serfling S. A., Hamlin H. Culture of beluga-hybrid "bester" sturgeon (H. huso $\times$ A. rnthenus) in closed-cycle culture systems in Florida // 4th Int. Simp. on Sturgeon : abstr. bull. 2001. AQ 51.

132. Some meristic characteristics of hybrids between Acipenser naccarii and Acipenser baeri / Arlati G. et al. // Journal of Applied Ichthyology. 1999. Vol. 15. P. 54-56.

133. Sperm-cell ultrastructure of North American sturgeons. V. The pallid sturgeon (Scaphirhynchus albus Richardson, 1905) / Di Lauro M. N. et al. // Canadian Journal of Zoology. 2001. Vol. 79. P. 802-808.

134. Spermatozoa motility in the Persian sturgeon (Acipenser persicus): effects of $\mathrm{pH}$, dilution rate, ions and osmolality / Alavi S. M. et all. // Reproduction. 2004. Vol. 128. 819-828.

135. Stock structure and homing fidelity in Gulf of Mexico sturgeon (Acipenser oxyrinchus desotoi) based on restriction fragment length polymorphism and sequence analyses of mitochondrial DNA / Stabile J. et al. // Genetics. 1996. Vol. 144. P. 767-775. 
136. Straughan D. J., Burnham-Curtis M. E., Fain S. R. Experimental search for forensically useful markers in the genus Scaphirhynchus // Journal of Applied Ichthyology. 2002. Vol. 18. P. 621-628.

137. Testicular development and serum sex steroid profiles during the annual sexual cycle of the male sturgeon hybrid, the bester / Mojazi Amiri B. et al. // Journal of Fish Biology. 1996. Vol. 48. P. 1039-1050.

138. The molecular phylogeny of the order Acipenseriformes revisited / Krieger J. et al. // Journal of Applied Ichthyology. 2008. Vol. 24. P. 36-45.

139. The preliminary evidence for low genetic diversity in the Chinese sturgeon (Acipenser sinensis) revealed by protein electrophoresis / Zhang S.-M. et al. // Zoological Research. 1999. Vol. 20. P. 93-98.

140. The use of AFLP in sturgeon identification / Congiu L. et al. // Journal of Applied Ichthyology. 2002. Vol. 18. P. 286-289.

141. Tranah G. J., Campton D. E., May B. Genetic evidence for hybridization of pallid and shovelnose sturgeon // Journal of Heredity. 2004. Vol. 95. P. 474-480.

142. Two cell lines from white sturgeon / Hedrick R. P. et al. // Transactions of the American Fisheries Society. 1991. Vol. 120. P. 528-534.

143. Unusual intraindividual variation of the nuclear 18S rRNA gene is widespread within the Acipenseridae / Krieger J. et al. // Journal of Heredity. 2006. Vol. 97. P. 218-225.

144. Use of RAPD markers to determine the genetic relationships among sturgeons (Acipenseridae, Pisces) / Comincini S. et al. // Fisheries Science. 1998. Vol. 64. P. 35-38.

145. Van Eenennaam A. L., Murray J. D., Medrano J. F. Karyotype of the American green sturgeon // Transactions of the American Fisheries Society. 1999. Vol. 128. P. $175-177$.

146. Van Eenennaam A. L., Murray J. D., Medrano J. F. Synaptonemal complex analysis in spermatocytes of white sturgeon, Acipenser transmontanus Richardson (Pisces, Acipenseridae), a fish with a very high chromosome number // Genome. 1998. Vol. 41. P. 51-61.

147. Variation in short tandem repeat sequences - a survey of twelve microsatellite loci for use as forensic identification markers / Urquhart A. et al. // International Journal of Legal Medicine. 1994. Vol. 107. P. 13-20.

148. Vasil'ev V. P. Mechanisms of Polyploid Evolution in Fish: Polyploidy in Sturgeons // Biology, Conservation and Sustainable Development of Sturgeons / Carmona R. et al. Netherlands : Springer Science + Business Media, 2009. P. 97117.

149. Waldman J. R., Hart J. T., Wirgin I. I. Stock composition of the New York Bight Atlantic sturgeon fishery based on analysis of mitochondrial DNA // Transactions of the American Fisheries Society. 1996. Vol. 125. P. 364-371.

150. Watson L. R., Groff J. M., Hedrick R. P. Replication and pathogenesis of white sturgeon iridovirus (WSIV) in experimentally infected white sturgeon (Acipenser transmontanus) juveniles and sturgeon cell lines // Diseases of Aquatic Organisms. 1998. Vol. 32. 173-184.

151. Welsh A. B., Blumberg M., May B. Identification of microsatellite loci in lake sturgeon (Acipenser fulvescens), and their variability in green sturgeon ( $A$. medirostris) // Molecular Ecology Resources. 2003. Vol. 3. P. 47-55. 
152. Welsh A. B., May B. Development and standartization of disomic microsatellite markers for lake sturgeon genetic studies // Journal of Applied Ichthyology. 2006. Vol. 22. P. 337-344.

153. Wirgin I., Stabile J. E., Waldman J. R. Molecular analysis in the conservation of sturgeons and paddlefish // Environmental Biology of Fishes. 1997. Vol. 48. P. 385-398.

154. Wolf C., Hübner P., Lüthy J. Differentiation of sturgeon species by PCR-RFLP // Food Res. Int. 1999. Vol. 32. P. 699-705.

155. Zhang S.-M., Wang D.-Q., Zhang Y.-P. Mitochondrial DNA variation, effective female population size and population history of the endangered Chinese sturgeon, (Acipenser sinensis) // Journal of Conservation Genetics. 2003. Vol. 4. P. 673683.

156. Zhang S.-M., Wu Q.-J., Zhang Y.-P. On the taxonomic status of the Yangtze sturgeon, Asian and American green sturgeons inferred from mitochondrial control region sequences // Current Zoology. 2001. Vol. 47. P. 632-639.

\section{REFERENCES}

1. Jenneckens, I., Meyer, J. N., Hörstgen-Schwark, G., May, B., Debus, L., \& Ludwig, A. (2001). A fixed allele at microsatellite LS-39 is characteristic for the black caviar producer Acipenser stellatus. Journal of Applied Ichthyology, 17, 39-42.

2. Hedrick, R. P., Speas, J., Kent, M. L., \& McDowell, T. (1985). Adeno-like virus associated with a disease of cultured white sturgeon (Acipenser transmontanus). Canadian Journal of Fisheries and Aquatic Sciences, 42, 1321-1325.

3. Adkison, M. A., Cambre, M., \& Hedrick, R. P. (1998). Identification of an iridovirus in Russian sturgeon (Acipenser gueldenstaedti) from Northern Europe. Bull. Eur. Ass. Fish Pathol., 18, 29-32.

4. Alavi, S. M. H. (2009). Sperm motility analysis for sturgeons. Cryopreservation of sturgeon sperm: International Workshop, 28 October, 2009: proceedings. Wuhan, China, 12-20.

5. Garrido-Ramos, M., Robles, A. F., de la Herran., Martínez-EspínJosé, R. E., Lorente, C. A., \& Ruiz-Rejón, M. (2009). Analysis of mitochondrial and nuclear DNA markers in old museum sturgeons yield insights about the species existing in Western Europe: A. sturio, A. naccarii and A. oxyrinchus. Springer Science \& Business Media, 25-49.

6. Hedrick, R. P., Groff, J. M., Mc Dowell, T. S., \& Wingfield, W. H. (1990). An iridovirus infection of the integument of the white sturgeon Acipenser transmontanus. Diseases of Aquatic Organisms, 6, 39-40.

7. Arefjev, V. A. (1991). Cytogenetic aspects of differences in the quality of spawners of reciprocal hybrids between "bester" and beluga sturgeon. Biol. Principles of commercial culture of sturgeons: collected papers. Moscow: VNIRO, 134-150.

8. Arefjev, V. A. (1989). Kariotype variability in successive generations after hybridization between the great sturgeon, Huso huso (L.), and the sterlet, Acipenser ruthenus (L.). Journal of Fish Biology, 35, 819-828.

9. Arefjev, V. A., \& Nikolaev A. I. (1993). Induced polyploidy in sturgeons: back to the problem in Russia. 2nd Int Simp. on Sturgeons: Abst. Bull. Moscow: VNIRO, 31-32.

10. Artyukhin, E. N. (1995). Morphological phylogeny of the Order Acipenseriformes. The Sturgeon Quarterly, 3, 6-8. 
11. Barmintsev, V. A., Chudinov, O. S., \& Abramova, A. B. (2001). Molecular and biological methods of identification and certification of sturgeons and their products. Fisheries and Aquaculture Journal, 1, 70-71.

12. Bemis, W. E., \& Findeis, E. K. (1994). The sturgeons' plight. Nature, 370, 602.

13. Beyea, M. M., Benfey, T. J., \& Kieffer, J. D. (2005). Hematology and stress physiology of juvenile diploid and triploid shortnose sturgeon (Acipenser brevirostrum). Fish Physiology and Biochemistry, 31, 303-313.

14. Billard, R., \& Lecointre, G. (2000). Biology and conservation of sturgeon and paddlefish. Reviews in Fish Biology and Fisheries, 10, 355-392.

15. Vasil'ev, A. S., Kuzmin, E. V., Luk'yanenko, V. V., Luk'yanenko, V. I., \& Khabarov, M. V. (1999). Biochemical analysis of decrease in phenotypic diversity in the Volgo-Caspian Russian sturgeon population. Journal of Applied Ichthyology, 15, 284-285.

16. Birstein, V. J. (2000). Sturgeon species and hybrids: can hybrids produce caviar? Environmental policy and law, 32, 210-214.

17. Birstein, V. J., Hanner, R., \& DeSalle, R. (1997). Phylogeny of the Acipenseriformes : cytogenetic and molecular approaches. Environmental Biology of Fishes, 48, 127-155.

18. Birstein, V. J., Betts, J., \& De Salle, R. (1998). Molecular identification of Acipenser sturio specimens: A warning note for recovery plans. Journal of Biological Conservation, 84, 97-101.

19. Birstein, Y. J., \& De Salle, R. (1998). Molecular phylogeny of Acipenserinae. Molecular phylogenetics and evolution, 9, 141-155.

20. Birstein, V. J., Doukakis, P., \& De Salle, R. (1999). Molecular phylogeny of Acipenserinae and black caviar species identification. Journal of Applied Ichthyology, 15, 12-16.

21. Birstein, V. J., Doukakis, P., \& De Salle, R. (2000). Polyphyletic genetic structure of the Russian sturgeon and caviar species identification. Journal of Conservation genetics, 1, 81-88.

22. Birstein, V. J., Doukakis, P., \& DeSalle, R. (2000). Polyphyly of mtDNA lineages in the Russian sturgeon, Acipenser gueldenstaedtii: forensic and evolutionary implications. Journal of Conservation Genetics, 1, 81-88.

23. Birstein, V. J., Poletaev, A. I., \& Goncharov, B. F. (1993). The DNA content in Eurasian sturgeon species determined by flow cytometry. Journal of Cytometry, 14, 337-383.

24. Birstein, V. J., \& Vasil'ev, V. P. (1987). Tetraploid-octoploid relationships and karyological evolution in the order Acipenseriformes (Pisces): karyotypes, nucleoli, and nucleolus-organizer regions in four acipenserid species. Journal of Conservation Genetics, 73, 3-12.

25. Bischof, R., \& Szalanski, A. L. (2000). Mitochondrial-DNA variation in pallid and shovelnose sturgeons, Scaphirhynchus (Pisces: Acipenseridae). Trans. Nebr. Acad. Sci., 26, 19-21.

26. Blacklidge, K. H., \& Bidwell, C. A. (1993). Three ploidy levels indicated by genome quantification in Acipenseriformes of North America. Journal of Heredity, $84,427-430$.

27. Bowen, B. W., \& Avise J. C. (1990). Genetic structure of Atlantic and Gulf of Mexico populations of sea bass, menhaden, and sturgeon: influence of zoogeographic factors and life-history patterns. Marine Biology, 107, 371-381. 
28. Brown, J. R., Beckenbach, A. T. \& Smith, M. J. (1993). Intraspecific DNA sequence variation of the mitochondrial control region of white sturgeon (Acipenser transmontanus). Molecular Biology Evol., 10, 326-341.

29. Brown, J. R., Beckenbach, A. T., \& Smith, M. J. (1992). Mitochondrial DNA length variation and heteroplasmy in populations of white sturgeon (Acipenser transmontanus). Journal of Conservation Genetics, 132, 221-228.

30. Brown, J. R., Beckenback, A. T., \& Smith, M. J. (1992). Influence of Pleistocene glaciations and human intervention upon mitochondrial DNA diversity in white sturgeon (Acipenser transmontanus) populations. Canadian Journal of Fisheries and Aquatic Sciences, 49, 358-367.

31. Watson, L. R., Yun, S. C., Groff, J. M., \& Hedrick, R. P. (1995). Characteristics and pathogenicity of a novel herpesvirus isolated from adult and sub adult white sturgeon Acipenser transmontanus. Diseases of Aquatic Organisms, 22, 199-210.

32. Hedrick, R. P., Mc Dowell, T. S., Groff, J. M., Yun, S., \& Wingfield, W. H. (1991). Characteristics of two viruses isolated from white sturgeon, Acipenser transmontanus. Second Intern. Symp. Virus. Lower Verteb.: proceedings. OR: Oregon State Univer. Press, 165-174.

33. Hett, A. K., Pitra, C., Jenneckens, I. \& Ludwig, A. (2005). Characterization of the Sox 9 gene in European Atlantic sturgeon (Acipenser sturio). Journal of Heredity, 96, 150-154.

34. Choudhury, A., \& Dick, T. A. (1998). The historical biogeography of sturgeons (Osteichthyes: Acipenseridae): a synthesis of phylogenetics, palaeontology and palaeogeography. Journal of Biogeography, 25, 623-640.

35. Rastorguev, S., Mugue, N., Volkov, A., \& Barmintsev, V. (2008). Complete mitochondrial DNA sequence analysis of Ponto-Caspian sturgeon species. Journal of Applied Ichthyology, 24, 46-49.

36. Billard, R., Cosson, J., Noveiri, S. B., \& Pourkazemi, M. (2004). Cryopreservation and short-term storage of sturgeon sperm, a review. Aquaculture, 236, 1-9.

37. Liu, L., Wei, Q., Guo, F., Zhang, J., \& Zhang, T. (2006). Cryopreservation of Chinese sturgeon (Acipenser sinensis) sperm. Journal of Applied Ichthyology, 22, 384-388.

38. Lanfredi, M., Rossi, R., Arlati, G., Bronzi, P., \& Fontana, F. (1997). Cytogenetic characterization of cell lines from six sturgeon species. 3rd Intern. Symposium on Sturgeon. Piacenza, Italy.

39. Fontana, F., Rossi, R., Lanfredi, M., Arlati, G., \& Bronzi, P. (1997). Cytogenetic characterization of cell lines from three sturgeon species. Journal of Caryologia, 50, 91-95.

40. DeSalle, R., \& Birstein, V. J. (1996). PCR identification of black caviar. Nature, 381, 197-198.

41. DeWoody, J. A., \& Avise, J. C. (2000). Microsatellite variation in marine, freshwater and anadromous fishes compared with other animals. Journal of Fish Biology, 56, 461-473.

42. Degani, G. (2002). Availability of protein and energy from throat protein sources in hybrid sturgeon Acipenser guldenstadti $\times$ A. bester. Aquaculture Research, 33, 725727.

43. Di Lauro, M. N., Kaboord, W. S., \& Walsh, R. A. (2000). Sperm-cell ultrastructure of North American sturgeons. IV. The lake sturgeon (Acipenser fulvescens Rafinisque, 1817). Canadian Journal of Zoology, 78, 438-447. 
44. Ferguson, M. M., Bernatchez, L., Gatt, M., Konkle, B. R., Lee, S., Malott, M. L. \& McKinley, R. S. (1993). Distribution of mitochondrial DNA variation in lake sturgeon (Acipenser fulvescens) from the Moose River basin, Ontario, Canada. Journal of Fish Biology, 43, 91-101.

45. Carlson, D. M., Pflieger, W. L., Trial, L. \& Haverland, P. S. (1985). Distribution, biology and hybridization of Scaphirhynchus albus and $S$. platorynchus in the Missouri and Mississippi rivers. Environmental Biology of Fish, 14, 51-59.

46. Dingerkus, G., \& Howell, W. M. (1976). Karyotypic analysis and evidence of tetraploidy in the North American paddlefish, Polyodon spathula. Science, 194, 842-843.

47. Wills, P. S., Sheehan, R. J., Heidinger, R., Sloss, B. L., \& Clevenstine R. (2002). Differentiation of pallid sturgeon and shovelnose sturgeon using an index based on meristics and morphometrics. American Fisheries Society Symp. 28, 249-258.

48. Doszpoly, A., \& Shchelkunov, I. S. (2010). Partial genome analysis of Siberian sturgeon alloherpesvirus suggests its close relation to AciHV-2. Acta Veterinaria Hungarica, 58, 269-274.

49. Doukakis, P., Birstein, V. J., \& De Salle, R. (2005). Intraspecific structure within three caviar-producing sturgeons (Acipenser gueldenstaedtii, A. stellatus and Huso huso) based on mitochondrial DNA analysis. Journal of Applied Ichthyology, 21, 457-460.

50. Dugo, M. A., Kreiser, B. R., Ross, S. T., Slack, W. T., Heise, R. J., \& Bowen, B. R. (2004). Conservation and management implications of finescale genetic structure of Gulf Sturgeon in the Pascagoula River, Mississippi. Journal of Applied Ichtyology, 20, 243-251.

51. Foster, O., Patrick, A. M.., Barculoo, J., Fontana, F., Lanfredi, M., Rossi, R., Bronzi, P., \& Arlati, G. (1995). Established cell lines from three sturgeon species. The Sturgeon Quarterly, 3, 6-7.

52. Jenneckens, I., Meyer, J. N., Debus, L., Pitra, C. \& Ludwig, A. (2000). Evidence of mitochondrial DNA clones of Siberian sturgeon, Acipenser baerii, within Russian sturgeon, Acipenser gueldenstaedtii, caught in the River Volga. Ecol. Lett., 3, 503508.

53. Robles, F., de la Herran, R., Ludwig, A., Ruiz-Rejon, C., Ruiz-Rejon, M., \& Garrido, R. M. (2004). Evolution of ancient satellite DNAs in sturgeon genomes. Gene, 338, 133-142.

54. Findeis, E. K. (1997). Osteology and phylogenetic interrelationships of sturgeons (Acipenseridae). Environmental Biology of Fishes, 48, 73-126.

55. Kelly, G. O., Kurobe, T., \& Waltzek, T. B. (2005). First detection and identification of koi herpesvirus (KHV) in Russian sturgeon (Acipenser gueldenstaedtii) and Atlantic sturgeon (Acipenser oxyrinchus) til genetic relationships among herpeslike viruses isolated from sturgeon. Journal of Aquatic Animal Health, 17, 297-303.

56. Li, M. F., Marrayatt, V., Annand, C., \& Odense, P. (1985). Fish cell culture: two newly developed cell lines from atlantic sturgeon (Acipenser oxyrhynchus) and guppy (Poecilia reticulata). Canadian Journal of Zoology, 63, 2867-2874.

57. Flajshans, M., \& Vajcova, V. (2000). Odd ploidy levels in sturgeon suggest a backcross of interspecific hexaploid sturgeon hybrids to evolutionary tetraploid and octaploid parental species. Folia Zoologica, 49, 133-138.

58. Fontana, F. (1994). Chromosomal nucleolar organizer regions in four sturgeon species as markers of karyotype evolution in Acipenseriformes (Pisces). Genome, $37,888-892$. 
59. Fontana, F., Jankovic, D., Zivkovic, S. (1975). Somatic chromosomes of Acipenser ruthenus L. Archives of biological sciences, 21, 1-2.

60. Fontana, F., Tagliavini, J., \& Congiu, L. (2001). Sturgeon genetics and cytogenetics: recent advancements and perspectives. Journal of Conservation Genetics, 111, 359-373.

61. Forlani, A., Fontana, F., \& Congiu, L. (2008). Isolation of microsatellite loci from the endemic and endangered Adriatic Sturgeon (Acipenser naccarii). Journal of Conservation Genetics, 9, 461-463.

62. Gardiner, B. G. (2004). Sturgeons as living fossils: circumscription, phylogeny, polyploidy and possible hybrid speciation. American Journal of Botany, 91, 707723.

63. Quattro, J. M., Greig T. W., Coykendall, D.K., Bowen, B.W., \& Baldwin J. D. (2002). Genetic issues in aquatic species management: the shortnose sturgeon (Acipenser brevirostrum) in the south-eastern United States. Journal of Conservation Genetic, 3, 155-166.

64. Mc Quown, E. C., Krueger, C. C., Kincaid, H. L., Gall, G. A. E., \& May, B. (2003). Genetic comparison of lake sturgeon populations: differentiation based on allelicfrequencies at seven microsatellite loci. Journal Great Lakes Research, 29, 313.

65. Gharaei, A., Pourkazemi, M., Rezvani, S., \& Mojazi Amiri, B. (2005). Genetic differences; and resemblance between Acipenser persicus and Acipenser gueldenstaedtii by means of RAPD technique. Iranian Journal of Fisheries Sciences, 14, 91-102.

66. Waldman, J. R., Nolan, K., Hart, J. T., \& Wirgin, I. I. (1996). Genetic differentiation of three key anadromous fish populations of the Hudson River. Estuaries, 19, 759-768.

67. Schrey, A. W., Sloss, B. L., Sheehan, R. J., Heidinger, R. C. \& Heist, E. J. (2007). Genetic discrimination of middle Mississippi River Scaphirhynchus sturgeon into pallid, shovelnose, and putative hybrids with multiple microsatellite loci. Journal of Conservation Genetics, 8, 683-693.

68. Campton, D. E., Bass, A. L., Chapman, F. A., \& Bowen, B. W. (2000). Genetic distinction of pallid, shovelnose, and Alabama sturgeon: emerging species and the US endangered species act. Journal of Conservation Genetics, 1, 17-32.

69. Ong, T.-L., Stabile, J., Wirgin, I., \& Waldman, J. R. (1996). Genetic divergence between Acipenser oxyrinchus oxyrinchus and Acipenser oxyrinchus desotoi as assessed by mitochondrial DNA sequencing analysis. Copeia, 2, 464-469.

70. de la Herran, R., Robles, F., Martinez-Espin, E., Lorente, J. A., Rejon, C. R., Garrido-Ramos, M. A., \& Rejon, M. R. (2004). Genetic identification of western Mediterranean sturgeons and its implication for conservation. Journal of Conservation Genetics, 5, 545-551.

71. Wirgin, I., Waldman, J. R., Rosko, J., Gross, R., Collins, M. R., Rogers, S. G., \& Stabile, J. (2000). Genetic structure of Atlantic sturgeon populations based on mitochondrial DNA control region sequenses. Transactions of the American Fisheries Society, 129, 476-486.

72. Ludwig, A., Belfiore, N. M., Pitra, C., Svirsky, V., \& Jenneckens, I. (2001). Genome duplication events and functionfl reduction of ploidy levels in sturgeon (Acipenser, Huso and Scaphirhynchus). Journal of Conservation Genetics, 158, 1203-1215. 
73. Robles, F., de la Herran, R., Ludwig, A., Ruiz-Rejon, C., Ruiz-Rejon, M., \& Garrido, R. M. (2005). Genomic organization and evolution of the 5S ribosomal DNA in the ancient fish sturgeon. Genome, 48, 18-28.

74. Gisbert, E., \& Doroshov, S. (2006). Allometric growth in green sturgeon larvae. Journal of Applied Ichthyology, 22, 202-207.

75. Grande, L., Bemis, W. E. (1991). Osteology and phylogenetic relationships of fossil and recent paddlefishes (Polyodontidae) with comments on the interrelationships of Acipenseriformes. Journal of Vertebrate Paleontology, 11, 1-121.

76. Guenette, S., Fortin, R., \& Rassart, E. (1993). Mitochondrial DNA variation in lake sturgeon (Acipenser fulvescens) from the St. Laurence River and James Bay Drainage Basins in Quebec, Canada. Canadian Journal of Fisheries and Aquatic Sciences, 50, 659-664.

77. Conte, F. S., Doroshov, S. I., Lutes, P. B., \& Strange, E. M. (1988). Hatchery manual for white sturgeon, Acipenser transmontanus R., with application to other North American Acipenseridae. Oakland: Div. Agric. Mat. Res., University of California, 88 .

78. Henderson-Arzapalo, A., \& King, T. L. (2002). Novel microsatellite markers for Atlantic sturgeon (Acipenser oxyrinchus) population delineation and broodstock management. Molecular ecology resources, 2, 437-439.

79. Ludwig, A., May, B., Debus, L., \& Jenneckens, I. (2000). Heteroplasmy in the mtDNA control region of sturgeon (Acipenser, Huso and Scaphirhynchus). Journal of Conservation Genetics, 156, 1933-1947.

80. Hett, A. K., \& Ludwig, A. (2005). SRY-related (Sox) genes in the genome of European Atlantic sturgeon (Acipenser sturio). Genome, 48, 181-186.

81. Hine, P. M., \& Wain, J. M. (1988). Ultrastructural and citochemical observations on the granulocytes of the sturgeons, Asipenser brevirostrum (Chondrostei). Journal of Fish Biology, 33, 235-245.

82. Barannikova, I. A,, Burtsev, L. A., Vlasenko, A. D., Gershannvieh A. D., Makarov, E. V., \& Nikoljukin, N. I. (1971). Hybridization of Acipenseridae and its practical significance. Rep. FAO/UNDP (TA). Rome, 328-334.

83. Congiu, L., Dupanloup, I., Patarnello, T., Fontana, F., Rossi, R., Arlati, G., \& Zane, L. (2001). Identification of interspecific hybrids by amplified fragment length polymorphism: the case of sturgeon. Molecular Ecology Resources, 10, 2355-2359.

84. Pyatskowit, J. D., Krueger, C. C., Kincaid, H. L., \& May, B. Inheritance of microsatellite loci in the polyploid lake sturgeon (Acipenser fulvescens). Genome, 44, 185-191.

85. Zane, L., Patarnello, T., Ludwig, A., Fontana, F., \& Congiu, L. (2002). Isolation and characterization of microsatellites in the Adriatic sturgeon (Acipenser naccarii). Molecular Ecology Notes, 2, 586-588.

86. Hedrick, R. P., Groff, J. M., Mc Dowell, T. S., \& Wingfield, W. H. (1991). Isolation of an epitheliotropic herpesvirus from white sturgeon (Acipenser transmontanus). Diseases of Aquatic Organisms, 11, 49-56.

87. Jahnichen, H., Kohlmann, R., \& Rennert, B. (1997). Juvenile growth of A. ruthenus and 4 defferent sturgeon hybrids. 3 International symposium on sturgeon: booklet abstracts. Piacenza, Italy, 71-72.

88. Kempter, J., Sadowski, J., Riecherd, M., Fichtner, D., Bergmann, S. M. (2007). First detection and identification of koi herpesvirus (KHV) in Russian sturgeon (Acipenser gueldenstaedtii) and Atlantic sturgeon (Acipenser oxyrinchus). 7 International Symposium on Viruses of Lower Vertebrates. Oslo, Norway, 15. 
89. Keyvanshokooh, S., Pourkazemi, M., \& Katbassi, M. R. (2007). The RAPD technique failed to identify sex-specific sequences in beluga (Huso huso). Journal of Applied Ichthyology, 23, 1-2.

90. King, T. L., Lubinski, B. A., \& Spidle, A. P. (2001). Microsatellite DNA variation in Atlantic sturgeon (Acipenser oxyrinchus oxyrinchus) and cross-species amplification in Acipenseridae. Journal of Conservation Genetics, 2, 103-119.

91. Krieger, J. (2000). Molecular phylogenetics and evolution of the North American sturgeon and paddlefish (Order Acipenseriformes). Doctor's thesis. Columbus, Ohio, USA: Ohio State Univ.

92. Krieger, J., \& Fuerst, P. A. (2002). Evidence of multiple alleles of the nuclear 18S ribosomal RNA gene in sturgeon. Journal of Applied Ichthyology, 18, 290-297.

93. Krieger, J., \& Fuerst, P. A. (2004). Characterization of nuclear 18S rRNA gene sequence diversity and expression in an individual lake sturgeon (Acipenser fulvescens). Journal of Applied Ichthyology, 20, 433-439.

94. Krieger, J., Fuerst, P. A. (2002). Evidence for a slowed rate of molecular evolution in the order Acipenseriformes. Molecular Biology Evolution, 19, 891-897.

95. Krieger, J., Fuerst, P. A., \& Cavender, T. M. (2000). Phylogenetic relationships of the North American sturgeons (Order Acipenseriformes) based on mitochondrial DNA sequences. Molecular Phylogenetics and Evolution, 16, 64-72.

96. Kuhajda, B. R., Mayden, R. L. (2001). Morphological comparisons of hatcheryreared specimens of Scaphirhynchus albus, S. platorhynchus, and S. albus, S. platorhynchus hybrids. Final Report US Fish and Wildlife Service Bismarck, 119.

97. Kurobe, T., Kelly, G. O., \& Waltzek, T. B. (2008). Revised phylogenetic relationships among herpesviruses isolated from sturgeons. Journal of Aquatic Animal Health, 20, 96-102.

98. Brown, J. R., Beckenbach, K., Beckenbach, A. T., \& Smith, M. J. (1996). Length variation, heteroplasmy and sequence divergence in the mitochondrial DNA of four species of sturgeon (Acipenser). Journal of Conservation Genetics, 142, 525-535.

99. Buroker, N. E., Brown, J. R., Gilbert, T. A., O'Hara, P. J., Beckenbach, A. T., Thomas, W. K., \& Smith, M. J. (1990). Length heteroplasmy of sturgeon mitochondrial DNA: an illegitimate elongation model. Genetics, 124, 157-163.

100. Carlson, D. M., Kettler, M. K., Fisher, S. E., \& Whitt, G. S. (1982). Low genetic variability in paddlefish populations. Copeia, 3, 721-723.

101. Ludwig, A. (2006). A sturgeon view on conservation genetics. European Journal of Wild Research, 52, 3-8.

102. Ludwig, A., \& Kirschbaum, F. (1998). Comparison of mitochondrial DNA sequences between the European and the Adriatic sturgeon. Journal of Fisheries Biology, 52, 1289-1291.

103. Ludwig, A., Debus, L., \& Jenneckens, I. (2002). A molecular approach for trading control of black caviar. International Review of Hydrobiology, 87, 661-674.

104. May, B., Krueger, C. C., \& Kincaid, H. L. (1997). Genetic variation at microsatellite loci in sturgeon: primer sequence homology in Acipenser and Scaphirhynchus. Canadian Journal of Fisheries and Aquatic Sciences, 54, 15421547.

105. May, B., \& Kuhajda, B. R. (1996). Systematics, taxonomy, and conservation status of the endangered Alabama sturgeon Scaphirhynchus suttkusi William and Clemmer (Actinopteiygii, Acipenseridae). Copeia, 2, 241-275. 
106. McQuown, E. C., Gall, G. A. E., \& May, B. (2002). Characterization and inheritance of six microsatellite loci in lake sturgeon. Transactions of the American Fisheries Society, 131, 299-307.

107. McQuown, E. C., Sloss, B. L., Sheehan, R. J., Rodzen, J., Tranah, G. J., \& May, B. (2000). Microsatellite analysis of genetic variation in sturgeon: new primer sequences for Scaphirhynchus and Acipenser. Transactions of the American Fisheries Society, 129, 1380-1388.

108. Zhang, S.-M., Deng, H., Wang, D., Zhang, Y.-P., \& Wu, Q.-J. (1999). Mitochondrial DNA length variation and heteroplasmy in the Chinese sturgeon (Acipenser sinensis). Acta Genetica Sinica, 26, 18-25.

109. Tagliavini, J., Conterio, F., Gandolfi, G., \& Fontana, F. (1999). Mitochondrial DNA sequences of six sturgeon species and phylogenetic relationships within Acipenseridae. Journal of Applied Ichthyology, 15, 17-22.

110. Miracle, A. L., \& Campton D. E. (1995). Tandem repeat sequence variation and length heteroplasmy in the mitochondrial DNA D-loop of the threatened Gulf of Mexico sturgeon A. oxyrichus desotoi. Journal of Heredity, 86, 22-21.

111. Doukakis, P., Birstein, V. J., Ruban, G. I., \& De Salle, R. (1999). Molecular genetic analysis among subspecies of two Eurasian sturgeon species, Acipenser baerii and A. stellatus. Molecular Ecology Resources, 12, 117-127.

112. Walsh, M. G., Bain, M. B., Squiers, T., Waldman, J. R., \& Wirgin, I. (2001). Morphological and genetic variation among shortnose sturgeon Acipenser brevirostrum from Adjacent and Distant Rivers. Estuaries, 24, 41-48.

113. Billard, R., Cosson, J., Fierville F., Brun, R., Rouault, T., \& Williot, P. (1999). Motility analysis and energetics of the Siberian sturgeon Asipenser baeri spermatozoa. Journal of Applied Ichthyology, 15, 199-203.

114. Jahnichen, M., Warnecre, D., Trolsch, E., Kohlmann, K., Bergler, H., \& Pluta, H. J. (1999). Motility and fertilizing capability of cryopreserved Acipenser ruthenus L. sperm. Journal of Applied Ichthyology, 15, 204-206.

115. Ludwig, A., Congiu, L., Pitra, C., Fickel, J., Gessner, J., Fontana, F., Patarnello, T., \& Zane, L. (2003). Nonconcordant evolutionary history of maternal and paternal lineages in Adriatic sturgeon. Molecular Ecology, 12, 3253-3264.

116. Toth, G. P., Ciereszko, A., Christ, S. A., \& Dobrowski, K. (1994). Objective analysis of sperm motility in the lake sturgeon (A. fulvescens): activation and inhibition conditions. Aquaculture, 154, 337-348.

117. La Patra, S. E., Groff, J. M., Jones, G. R., Munn, B., Patterson, T. L., Holt, R. A., Hauck, A. K., \& Hedrick, R. P. (1994). Occurrence of white sturgeon iridovirus infections among cultured white sturgeon in the Pacific Northwest. Aquaculture, 126, 201-210.

118. Mojazi Amiri, B., Maebayashi, M., Hara, A., Adachi, S., \& Yamauchi, K. (1996). Ovarian development and serum sex steroid and vitellogenin profiles in the female cultured sturgeon hybrid, the bester. Journal of Fish Biology, 47, 1164-1178.

119. Kynard, B., Zhuang, P., Zhang, L., Zhang, T., \& Zhang, Z. (2002). Ontogenetic behavior and migration of Volga river Russian Sturgeon, Acipenser gueldenstaedtli, with a note on adaptive significance of body color. Environmental Biology of Fish, 65, 411-421.

120. Phelps, S. R., \& Allendorf, F. W. (1983). Genetic identity of pallid and shovelnose sturgeon (Scaphirhynchns albus and S. platorynchus). Copeia, 3, 696-700. 
121. Birstein, V.J., Doukakis, P., Sorkin, B., \& DeSalle, R. (1998). Population aggregation analysis of three caviar-producing species of sturgeons and implications for the species identification of black caviar. Journal of Conservation Biology, 12, 766-775.

122. Smith, C. T., Nelson, R. J., Pollard, S., Rubidge, E., Mc Kay, S. J., Rodzen, J., May B., \& Koop, B. (2002). Population genetic analysis of white sturgeon (Acipenser fulvescens) in the Fraser River. Journal of Applied Ichthyology, 18, 307-312.

123. Zhang, S.-M., Deng, H., Yang, Y., \& Wu, Q.-J. (2000). Population genetic structure and genetic diversity of the Chinese sturgeon (Acipenser sinensis) based on random amplified polymorphic DNA analysis. Chinese Journal of Oceanology and Limnology, 31, 1-7.

124. Grunwald, G., Stabile, J., Waldman, J. R., Gross, R., \& Wirgin, I. (2002). Population genetics of shortnose sturgeon Acipenser brevirostrum based on mitochondrial DNA control region sequences. Molecular Ecology Resources, 11, 1885-1898.

125. Pourkazemi, M., Skibinski, D. O. F., \& Beardmore, J. A. (1999). Application of mtDNA d-loop region for the study of Russian sturgeon population structure from Iranian coastline of the Caspian Sea. Journal of Applied Ichthyology, 15, 23-28.

126. Tranah, G. J., Kincaid, H. L., Krueger, C. C., Campton, D. E. \& May, B. (2001). Reproductive isolation in sympatric populations of pallid and shovelnose sturgeon. North American Journal of Fisheries Management, 21, 367-373.

127. Richmond, A. M., \& Kynard, B. (1995). Ontogenic Behaviour of Shortnose Sturgeon, Acipenser brevirostrum. Copeia, 41, 172-182.

128. Robinson, M. R., \& Ferguson, M. M. (2004). Genetics of North American Acipenseriformes. Sturgeons and Paddlefishes of North America. Le Breton, G. T. O., William, F., Beamish, H., McKinley, R. S. (Eds.). Netherlands: Springer, 217230.

129. Rodzen, J. A., \& May, B. (2002). Inheritance of microsatellite loci in the white sturgeon (Acepenser transmontanus). Genome, 45, 1064-1076.

130. Rodzen, J. A., Famula, T. R., \& May, B. (2004). Estimation of parentage and relatedness in the polyploid white sturgeon (Acipenser transmontanus) using a dominant marker approach for duplicated microsatellite loci. Aquaculture, 232, 165-182.

131. Serfling, S. A., \& Hamlin, H. (2001). Culture of beluga-hybrid "bester" sturgeon (H. huso x A. ruthenus) in closed-cycle culture systems in Florida. 4th Int. Simp. on Sturgeon: Abstr. Bull., AQ 51.

132. Arlati, G., Hernando, J. A., Poliakova-Belysceva, A., \& Soriguer, M. C. (1999). Some meristic characteristics of hybrids between Acipenser naccarii and Acipenser baeri. Journal of Applied Ichthyology, 15, 54-56.

133. Di Lauro, M. N., Walsh, R. A., Peiffer, M., \& Bennet, R. M. (2001). Sperm-cell ultrastructure of North American sturgeons. V. The pallid sturgeon (Scaphirhynchus albus Richardson, 1905). Canadian Journal of Zoology, 79, 802808.

134. Alavi, S. M., Cosson, J., Karami, M., Amiri, B. M., \& Akhoundzadeh, M. A. (2004). Spermatozoa motility in the Persian sturgeon (Acipenser persicus): effects of $\mathrm{pH}$, dilution rate, ions and osmolality. Reproduction, 128, 819-828. 
135. Stabile, J., Waldman, J. R., Parauka, F., \& Wirgin, I. (1996). Stock structure and homing fidelity in Gulf of Mexico sturgeon (Acipenser oxyrinchus desotoi) based on restriction fragment length polymorphism and sequence analyses of mitochondrial DNA. Genetics, 144, 767-775.

136. Straughan, D. J., Burnham-Curtis, M. E., \& Fain, S. R. (2002). Experimental search for forensically useful markers in the genus Scaphirhynchus. Journal of Applyed Ichthyology, 18, 621-628.

137. Mojazi Amiri, B., Maebayashi, M., Adachi, S., \& Yamauchi, K. (1996). Testicular development and serum sex steroid profiles during the annual sexual cycle of the male sturgeon hybrid, the bester. Journal of Fish Biology, 48, 1039-1050.

138. Krieger, J., Hett, A. K., Fuerst, P. A., Artyukhin, E. N., \& Ludwig, A. (2008). The molecular phylogeny of the order Acipenseriformes revisited. Journal of Applied Ichthyology, 24, 36-45.

139. Zhang, S.-M., Yang, Y., Deng, H., Wei, Q.-W., \& Wu, Q.-J. (1999). The preliminary evidence for low genetic diversity in the Chinese sturgeon (Acipenser sinensis) revealed by protein electrophoresis. Zoological Research, 20, 93-98.

140. Congiu, L., Fontana, F., Patarnello, T., Rossi, R., \& Zane, L. (2002). The use of AFLP in sturgeon identification. Journal of Applied Ichthyology, 18, 286-289.

141. Tranah, G. J., Campton, D. E., \& May, B. (2004). Genetic evidence for hybridization of pallid and shovelnose sturgeon. Journal of Heredity, 95, 474-480.

142. Hedrick, R. P., McDowell, T. S., Rosemark, R., Aronstein, D., \& Lannan, C. N. (1991). Two cell lines from white sturgeon. Transactions of the American Fisheries Society, 120, 528-534.

143. Krieger, J., Hett, A. K., Fuerst, P. A., Birstein, V. J., \& Ludwig, A. (2006). Unusual intraindividual variation of the nuclear $18 \mathrm{~S}$ rRNA gene is widespread within the Acipenseridae. Journal of Heredity, 97, 218-225.

144. Comincini, S., Lanfredi, M., Rossi, R., Fontana, F. (1998). Use of RAPD markers to determine the genetic relationships among sturgeons (Acipenseridae, Pisces). Fisheries Science, 64, 35-38.

145. Van Eenennaam, A. L., Murray, J. D., \& Medrano, J. F. (1999). Karyotype of the American green sturgeon. Transactions of the American Fisheries Society, 128, 175-177.

146. Van Eenennaam, A. L., Murray, J. D., \& Medrano, J. F. (1998). Synaptonemal complex analysis in spermatocytes of white sturgeon, Acipenser transmontanus Richardson (Pisces, Acipenseridae), a fish with a very high chromosome number. Genome, 41, 51-61.

147. Urquhart, A., Kimpton, C. P., Downes, T. J., \& Gill, P. (1994). Variation in short tandem repeat sequences - a survey of twelve microsatellite loci for use as forensic identification markers. International Journal of Legal Medicine, 107, 1320.

148. Vasil'ev, V. P. (2009). Mechanisms of Polyploid Evolution in Fish: Polyploidy in Sturgeons. Biology, Conservation and Sustainable Development of Sturgeons. Netherlands: Springer Science + Business Media, 97-117.

149. Waldman, J. R., Hart, J. T., \& Wirgin, I. I. (1996). Stock composition of the New York Bight Atlantic sturgeon fishery based on analysis of mitochondrial DNA. Transactions of the American Fisheries Society, 125, 364-371.

150. Watson, L. R., Groff, J. M., \& Hedrick, R. P. (1998). Replication and pathogenesis of white sturgeon iridovirus (WSIV) in experimentally infected white sturgeon 
Acipenser transmontanus juveniles and sturgeon cell lines. Diseases of Aquatic Organisms, 32, 173-184.

151. Welsh, A. B., Blumberg M., \& May B. (2003). Identification of microsatellite loci in lake sturgeon Acipenser fulvescens, and their variability in green sturgeon $A$. medirostris. Molecular Ecology Resources, 3, 47-55.

152. Welsh, A. B., \& May, B. (2006). Development and standartization of disomic microsatellite markers for lake sturgeon genetic studies. Journal of Applied Ichthyology, 22, 337-344.

153. Wirgin, I., Stabile, J. E., \& Waldman, J. R. (1997). Molecular analysis in the conservation of sturgeons and paddlefish. Environmental Biology of Fishes, 48, 385-398.

154. Wolf, C., Hübner, P., \& Lüthy, J. (1999). Differentiation of sturgeon species by PCR-RFLP. Food Res. Int., 32, 699-705.

155. Zhang, S.-M., Wang, D.-Q., \& Zhang, Y.-P. (2003). Mitochondrial DNA variation, effective female population size and population history of the endangered Chinese sturgeon, Acipenser sinensis. Journal of Conservation Genetics, 4, 673-683.

156. Zhang, S.-M., Wu, Q.-J., \& Zhang, Y.-P. (2001). On the taxonomic status of the Yangtze sturgeon, Asian and American green sturgeons inferred from mitochondrial control region sequences. Current Zoology, 47, 632-639. 